\title{
ROLE OF ANTIOXIDANTS, ENVIRONMENTAL EXPOSURE TO LEAD AND CADMIUM IN SPONTANEOUS ABORTION.
}

\author{
Ahmed M.H. , El-Desouky N.A.* and Rashed L. A.**
}

FROM

Industrial Medicine \& Occupational Disease and Departments of Forensic Medicine \& Toxicology*, and Medical Biochemistry**, Faculty of Medicine, Cairo University.

\begin{abstract}
Background and rationale: Pregnant women exposed to even low levels of environmental lead and cadmium may experience adverse perinatal effects. Aim of the work: The aim of the present study was to search for any relation between the environmental exposure to lead and cadmium and spontaneous abortion and, to emphasize the truth about the antioxidants and their relation as a mechanism for such relation if present. Subjects and methods: 38 women were included in this study. They were divided into 2 groups: Group I: Included 14 normal pregnant women (control group). Group II: Included 24 women with spontaneous abortion (cases). All women were in their first trimester. The following investigations were performed for every woman: lead, cadmium and serum zinc, serum vitamin C, Serum glutathione and serum malondialdehyde levels. Results: Cases had statistically significant higher blood lead, cadmium levels and malondialdehyde level and, statistically significant lower serum zinc, vitamin $\mathrm{C}$ and glutathione levels than controls. Conclusion and Recommendations: The obtained results indicate that spontaneous abortion is accompanied by a profound disruption of the prooxidant-antioxidant homeostasis towards oxidative stress. Increased free radical activity produced by environmental exposure to lead and cadmium has been implicated in the pathogenesis of spontaneous abortion. Industrial areas have been accused as environmentally polluted with both lead and cadmium.
\end{abstract}




\section{Introduction}

Lead is perhaps the longest used and best recognized toxic environmental chemical, yet it continued be used recklessly until only very recently. Lead is thus a lesson in the limitations and strengths of science, human conscience and common sense. Lead has been tested and found to be capable of eliciting a positive response in an extraordinarily wide range of biological and biochemical tests; among them tests for enzyme inhibition, fidelity of DNA synthesis, mutation, chromosome aberrations, cancer and birth defects. It reacts or complexes with many biomolecules and adversely affects the reproductive, nervous, gastrointestinal, immune, renal, cardiovascular, skeletal, muscular and hematopoietic systems as well as developmental processes (Johnson, 1998).

Numerous sources of lead exposure exist. environmental exposures affect the entire population, and include leaded paint, soil and dust contaminated by lead paint, leaded gasoline automobile exhaust, and industrial waste, airborne lead from automobile exhaust and industrial emissions, water contaminated via lead pipes and lead solder, and food contaminated via lead-soldered cans (Rhainds \& Levallois, 1997).
Cadmium is present in trace amounts in most environmental media including soil and water. Substantial additional amounts are added to the environment as a consequence of human activities. Sources include smelting and mining, electroplating, smoking, waste disposal, municipal incineration and, land application of solid waste disposal. The most important environmental source of inhaled cadmium is tobacco smoke (Newman-Taylor, 1998).

Cadmium has been recognised as one of the most toxic industrial and environmental elements of which there is a continuing toxic hazard to human exposure (Kojima, et al., 1992). In addition to its classification as a human carcinogen by the International Agency for Research on Cancer (Saplakoglu \& Iscan, 1998), it produces a wide spectrum of toxic effects to a number of organ systems including the kidneys (Elinder \& Nordberg, 1998); the lungs (Hart, et al., 1995); the cardiovascular (Jarup, 1998); the reproductive (Norberg, 1998) and the eyes (Cekic, 1998).

During the past decades, increased attention has been focused on potentially adverse effects on human reproduction function caused by both occupational and environmental exposures. The concern over such effects has been emphasized in the promulgation of occupational health 
and safety standards on exposure limits for inorganic limits (Fischbein, 1998).

The long-term exposure of a pregnant woman to even low concentrations of heavy metals (cadmium, lead, mercury and others) demonstrate cumulative properties and, may often lead to irreversible disorders in fetal growth and development. Lead and cadmium microintoxication seems to be a common danger for every organism, especially a developing one, since no regulatory mechanisms protect it against these metals (Semczuk \& Semczuk, 2001).

Pregnant women exposed to even low levels of environmental lead and cadmium may experience adverse perinatal effects (Falcon, et al. 2002).

Miscarriages, anemia and toxemia were more often observed in pregnant women exposed to high lead doses. Epidemiological studies show that men's exposure to lead or mercury intoxication, may account for spontaneous miscarriages in their partners. The data in the available literature imply the group of metals of proven embryotoxic and teratogenic activity including arsenic, cadmium, lead, mercury and uranium. On one hand, these are metals of highest toxicological potential, and on the other, they are most abundant in our surroundings (Semczuk \& Semczuk, 2001).
The aim of the present study was to search for any relation between the environmental exposure to lead and cadmium and spontaneous abortion and, to emphasize the truth about the antioxidants and their relation as a mechanism for such relation if present.

\section{Subjects and Methods:}

This study has been carried out on 38 women. They were classified into 2 groups:

Group I: It included 14 normal pregnant women (control).

Group II: It included 24 women with spontaneous abortion (cases).

According to the residence areas, group II is classified into 6 groups (1,2,3,4,5 \& 6) ( Shoubra, Helwan, Embaba, Bulak, Misr El Kadima and Ben El Sarayat) respectively.

All women were in their first trimester and they were age matching.

Full history taking about their possible exposure to radiation, drugs, trauma, fevers, diseases and residence that may be associated with abortion then full clinical examination was performed.

\section{Laboratory assays:}

I- Estimation of lead, cadmium and zinc levels: 
Blood lead $(\mathrm{Pb})$, cadmium $(\mathrm{Cd})$ and zinc ( $\mathrm{Zn}$ ) levels were estimated using a flameless atomic absorption spectrophotometry (Varian SpectrAA 220) equipped with a graphite furnace Auto-sampler (GTA-110). The spectral line used for $\mathrm{Pb}$, $\mathrm{Cd}$ and $\mathrm{Zn}$ determination were $283.3 \mathrm{~nm}$., $228.8 \mathrm{~nm}$. and $213.86 \mathrm{~nm}$. respectively according to the method described by Fernandez (1975).

\section{II- Methodology of antioxidants:}

1- Determination of glutathione (GSH) level:

Virtually all of the non-protein sulphhydryl of the erythrocyte in the form of GSH-S`-S` dithiobis (2` nitrobenzoic acid) is a disulphide compound that is threadly produced by $\mathrm{SH}$ compounds forming a highly colored yellow anion whose absorbants were measured at $412 \mathrm{~nm}$. (Beuther, 1984).

\section{2- Determination of Vitamin C level:}

Blood vitamin $\mathrm{C}$ measurement was based on interaction of ascorbic acid with folin reagent. Ascorbic acid level was obtained from standard curve (Jagota \& Dany, 1982).

\section{3- Determination of malondialde-} hyde (MDA) level:

$-0.1 \mathrm{ml}$ of serum was mixed with equal volume of $8.1 \%$ Na dodecyl sulfate (SDS), $0.75 \mathrm{ml}$ acetic acid at $\mathrm{pH} 3.5$.
$-0.75 \mathrm{ml}$ of freshly prepared thiobarbituric acid (TBA) after boiling for $60 \mathrm{~min}$. the resulting chromogen was extracted with $2.5 \mathrm{ml}$ of N-butanol and its absorbants was measured at $532 \mathrm{~nm}$ (Ohkawo et al. (1979).

\section{The statistical methods:}

Data were statistically described in terms of mean \pm standard deviation ( SD), frequencies (number of cases) and relative frequencies (percentages) when appropriate. Comparison of numerical data between cases and control groups was done using Mann Whitney U test for independent samples. Comparison of serum cadmium level between the different residence was done using Kruskal Wallis analysis of variance (ANOVA) test with Mann Whitney post hoc multiple 2-group comparisons. For comparing categorical data, Chi square (2) test was performed. Yates correction was used instead when the frequency is less than 10. Correlation between various variables was done using Spearman rank order correlation. A probability value ( $\mathrm{p}$ value) less than 0.05 was considered statistically significant. All statistical calculations were done using computer programs Microsoft Excel version 7 (Microsoft Corporation, NY, USA) and SPSS (Statistical Package for the Social Science; SPSS Inc., Chicago, IL, USA) statistical program. 


\section{Results}

\section{Descriptive data:}

The age in group I and II ranged between 21-32 years and 20-35 years with means of $26.29 \pm 3.79$ years and $28.17 \pm$ 4.53 years respectively (Table- 1 ).

The blood Lead level in group I and II ranged between 7.49-8.32 $\mu \mathrm{g} / \mathrm{dL}$ and 8.87$13.39 \mu \mathrm{g} / \mathrm{dL}$ with means of $7.977 \pm .3 \mu \mathrm{g} /$ $\mathrm{dL}$ and $10.559 \pm 1.317 \mu \mathrm{g} / \mathrm{dL}$ respectively (Table-1).

The cadmium level in group I and II ranged between 2.28-3.1 $\mu \mathrm{g} / \mathrm{L}$ and 1.27$4.5 \mu \mathrm{g} / \mathrm{L}$ with means of $2.75 \pm 0.23 \mu \mathrm{g} / \mathrm{L}$ and $3.12 \pm 0.81 \mu \mathrm{g} / \mathrm{L}$ respectively (Table$1)$.

The zinc level in group I and II ranged between $0.8-0.92 \mathrm{mg} / \mathrm{L}$ and $0.61-0.85 \mathrm{mg} /$ $\mathrm{L}$ with means of $0.86 \pm 0.04 \mathrm{mg} / \mathrm{L}$ and $0.76 \pm 0.06 \mathrm{mg} / \mathrm{L}$ respectively (Table- 1 ).

The GSH level in group I and II ranged between $4.92-6.23 \mathrm{mmol} / \mathrm{Hb}$ and 2.96-4.92 $\mathrm{mmol} / \mathrm{Hb}$ with means of $5.36 \pm$ $0.4 \mathrm{mmol} / \mathrm{Hb}$ and $3.9 \pm 0.61 \mathrm{mmol} / \mathrm{Hb} \mathrm{re}-$ spectively (Table-1).

The Vitamin C level in group I and II ranged between $0.92-1.93 \mathrm{mg} / \mathrm{dl}$ and $0.53-$ $1.02 \mathrm{mg} / \mathrm{dl}$ with means of $1.34 \pm 0.29 \mathrm{mg} /$ $\mathrm{dl}$ and $0.77 \pm 0.15 \mathrm{mg} / \mathrm{dl}$ respectively (Table-1).
The MDA level in group I and II ranged between $0.62-1.02 \mathrm{mmol} / \mathrm{L}$ and $0.76-2.01 \mathrm{mmol} / \mathrm{L}$ with means of $0.81 \pm$ $0.12 \mathrm{mmol} / \mathrm{L}$ and $1.45 \pm 0.43 \mathrm{mmol} / \mathrm{L}$ respectively (Table-1).

\section{Spearman's correlations:}

There was positive correlation between both lead and cadmium and the gestational age $(\mathrm{p}<0.049 *$ and $\mathrm{p}<0.000 *$ respectively) (Table-3).

There was positive correlation between both lead and cadmium and the residence ( $\mathrm{p}<0.008^{*}$ and $\mathrm{p}<0.057^{*}$ respectively) (Table-3).

There was positive correlation between both lead and cadmium and zinc $(\mathrm{p}<$ $0.000 *$ and $\mathrm{p}<0.023 *$ respectively) (Table-3).

There was positive correlation between both lead and cadmium and GSH ( $\mathrm{p}<$ $0.000 *$ and $\mathrm{p}<0.01 *$ respectively) (Table$3)$.

There was positive correlation between both lead and cadmium and vitamin $\mathrm{C}(\mathrm{p}<$ $0.000 *$ and $\mathrm{p}<0.047 *$ respectively) (Table-3).

There was positive correlation between both lead and cadmium and MDA ( $\mathrm{p}<$ $0.000 *$ and $\mathrm{p}<0.01 *$ respectively) (Table$3)$. 
There was no correlation between both lead and cadmium and the age.

\section{Mann Whitney U test:}

There was statistically significant higher lead, cadmium and MDA in cases than controls $\left(\mathrm{p}<0.000^{*}, \mathrm{p}<0.039^{*}\right.$ and $\mathrm{p}<0.000 *$ respectively) (Table-2) (figure2, 3 and 7).

There was statistically significant lower zinc, GSH and Vitamin C in cases than controls ( $\mathrm{p}<0.000 *$ for all) (Table-2) (figure-4, 5 and 6 ).

$66.66 \%$ of cases were living in industrially polluted areas with lead and cadmi- um $33.33 \%$ in Shoubra El-Khema and $33.33 \%$ in Helwan while the remaining percent were living in other areas) (Figure1).

There was a significant difference between the relative percent of control and cases in their residence areas.

Table-4: is showing the number and percentage of the resident areas for both controls and cases.

Table-5 and 6: are showing the Chisquare test for the residence areas for cases according to both lead and cadmium respectively. 
Table-1: Minimum, maximum and Mean \pm S.D of age (years) and lead ( $\mu \mathrm{g} / \mathrm{dL})$, cadmium $(\mu \mathrm{g} / \mathrm{L})$, zinc $(\mathrm{mg} / \mathrm{L}), \mathrm{GSH}(\mathrm{mmol} / \mathrm{Hb})$, Vitamin C $(\mathrm{mg} / \mathrm{dl})$ and MDA $(\mathrm{mmol} / \mathrm{L})$ in group I and II as well as their statistical significance.

\begin{tabular}{|c|c|c|c|c|c|}
\hline Variable & Group & Minimum & Maximum & Mean \pm S.D & $\begin{array}{l}\text { Statistical } \\
\text { significance }\end{array}$ \\
\hline Age & $\begin{array}{l}\text { Group I } \\
\text { Group II }\end{array}$ & $\begin{array}{l}21 \\
20\end{array}$ & $\begin{array}{l}32 \\
35\end{array}$ & $\begin{array}{l}26.29 \pm 3.79 \\
28.17 \pm 4.53\end{array}$ & 0.202 \\
\hline $\begin{array}{c}\text { Lead } \\
(\mu \mathrm{g} / \mathrm{dL})\end{array}$ & $\begin{array}{l}\text { Group I } \\
\text { Group II }\end{array}$ & $\begin{array}{l}7.49 \\
8.87\end{array}$ & $\begin{array}{c}8.32 \\
13.39\end{array}$ & $\begin{array}{c}7.977 \pm 3 \\
10.559 \pm 1.317\end{array}$ & $0.000 *$ \\
\hline $\begin{array}{l}\text { Cadmium } \\
(\mu \mathrm{g} / \mathrm{L})\end{array}$ & $\begin{array}{l}\text { Group I } \\
\text { Group II }\end{array}$ & $\begin{array}{l}2.18 \\
2.27\end{array}$ & $\begin{array}{l}3.1 \\
4.5\end{array}$ & $\begin{array}{c}2.74 \pm 0.25 \\
3.2 \pm 0.65\end{array}$ & $0.039 *$ \\
\hline $\begin{array}{c}\text { Zinc } \\
(\mathrm{mg} / \mathrm{L})\end{array}$ & $\begin{array}{l}\text { Group I } \\
\text { Group II }\end{array}$ & $\begin{array}{c}0.8 \\
0.61\end{array}$ & $\begin{array}{l}0.92 \\
0.85\end{array}$ & $\begin{array}{l}0.86 \pm 0.04 \\
0.76 \pm 0.06\end{array}$ & $0.000 *$ \\
\hline $\begin{array}{c}\mathrm{GSH} \\
(\mathrm{mmol} / \mathrm{Hb})\end{array}$ & $\begin{array}{l}\text { Group I } \\
\text { Group II }\end{array}$ & $\begin{array}{l}4.92 \\
2.96\end{array}$ & $\begin{array}{l}6.23 \\
4.92\end{array}$ & $\begin{array}{l}5.36 \pm 0.4 \\
3.9 \pm 0.61\end{array}$ & $0.000 *$ \\
\hline $\begin{array}{l}\text { Vitamin C } \\
(\mathrm{mg} / \mathrm{dl})\end{array}$ & $\begin{array}{l}\text { Group I } \\
\text { Group II }\end{array}$ & $\begin{array}{l}0.92 \\
0.53\end{array}$ & $\begin{array}{l}1.93 \\
1.02\end{array}$ & $\begin{array}{l}1.34 \pm 0.29 \\
0.77 \pm 0.15\end{array}$ & $0.000 *$ \\
\hline $\begin{array}{c}\text { MDA } \\
(\mathrm{mmol} / \mathrm{L})\end{array}$ & $\begin{array}{l}\text { Group I } \\
\text { Group II }\end{array}$ & $\begin{array}{l}0.62 \\
0.76\end{array}$ & $\begin{array}{l}1.02 \\
2.01\end{array}$ & $\begin{array}{l}0.81 \pm 0.12 \\
1.45 \pm 0.43\end{array}$ & $0.000 *$ \\
\hline
\end{tabular}


Table-2: Mann-Whitney U test of age (years), gestational age (weeks), lead ( $\mu \mathrm{g} / \mathrm{dL})$, cadmium $(\mu \mathrm{g} / \mathrm{L})$, serum zinc $(\mathrm{mg} / \mathrm{L}), \mathrm{GSH}(\mathrm{mmol} / \mathrm{Hb})$, vitamin $\mathrm{C}(\mathrm{mg} / \mathrm{dl})$ and MDA (mmol/L) for cases as well as their statistical significance.

\begin{tabular}{|l|c|c|c|c|c|c|c|}
\hline Variable & $\begin{array}{c}\text { Rank sum } \\
\text { group 1 }\end{array}$ & $\begin{array}{c}\text { Rank sum } \\
\text { group 2 }\end{array}$ & $\mathrm{U}$ & $\mathrm{Z}$ & P-level & $\begin{array}{c}\text { Adjuste } \\
\mathrm{d} Z\end{array}$ & P-level \\
\hline Age & 510 & 231 & 126 & -1.270 & 0.203 & -1.275 & 0.202 \\
Gestational age & 460 & 281 & 160 & -0.242 & 0.808 & -0.248 & 0.804 \\
Lead & 636 & 105 & 0 & -5.083 & $0.000^{*}$ & -5.089 & $0.000^{*}$ \\
Cadmium & 536 & 205 & 100 & -2.057 & $0.039^{*}$ & -2.060 & $0.039^{*}$ \\
Zinc & 324 & 417 & 24 & -4.357 & $0.000^{*}$ & -4.362 & $0.000^{*}$ \\
GSH & 302 & 439 & 2 & -5.023 & $0.000^{*}$ & -5.030 & $0.000^{*}$ \\
Vitamin C & 310 & 431 & 10 & -4.781 & $0.000^{*}$ & -4.792 & $0.000^{*}$ \\
MDA & 608 & 133 & 28 & -4.236 & $0.000^{*}$ & -4.244 & $0.000^{*}$ \\
\hline
\end{tabular}


Table-3: Spearman's Rank order correlation between the lead $(\mu \mathrm{g} / \mathrm{dL})$ levels and cadmium ( $\mu \mathrm{g} / \mathrm{L})$ and, age (years), gestational age (weeks), zinc (mg/L), GSH (mmol/ $\mathrm{Hb})$, vitamin $\mathrm{C}(\mathrm{mg} / \mathrm{dl})$ and MDA $(\mathrm{mmol} / \mathrm{L})$ in both group I and II as well as their statistical significance.

\begin{tabular}{|l|c|c|c|}
\hline Pair of Variables & $\begin{array}{c}\text { Number of } \\
\text { cases }\end{array}$ & Spearman R & P-value \\
\hline Age and lead & 38 & 1.25 & 0.219 \\
\hline Age and cadmium & 38 & -0.163 & 0.870 \\
\hline Gestational age and Lead & 38 & 0.321 & $0.049^{*}$ \\
\hline Gestational age And cadmium & 38 & -0.255 & $0.000^{*}$ \\
\hline Residence and lead & 38 & -0.526 & $0.008^{*}$ \\
\hline Residence and cadmium & 38 & 0.392 & $0.057^{*}$ \\
\hline Zinc and Lead & 38 & -0.714 & $0.000^{*}$ \\
\hline Zinc and cadmium & 38 & -0.178 & $0.023^{*}$ \\
\hline GSH and Lead & 38 & -0.684 & $0.000^{*}$ \\
\hline GSH and cadmium & 38 & -0.410 & $0.010^{*}$ \\
\hline Vitamin C and lead & 38 & -0.518 & $0.000^{*}$ \\
\hline Vitamin C and cadmium & 38 & -0.324 & $0.047^{*}$ \\
\hline MDA and lead & 38 & 0.733 & $0.000^{*}$ \\
\hline MDA and cadmium & 38 & 0.411 & $0.010^{*}$ \\
\hline
\end{tabular}


Table-4: Number and percentage in group I and II concerning their residence.

\begin{tabular}{|l|c|c|c|}
\hline Variable & Group & $\begin{array}{c}\text { Number of con- } \\
\text { trols \& cases }\end{array}$ & $\begin{array}{c}\text { percent of } \\
\text { controls \& cases }\end{array}$ \\
\hline Shoubra & Group I & 0 & $0 \%$ \\
group 1) & Group II & 8 & $33.33 \%$ \\
\hline Helwan & Group I & 2 & $14.29 \%$ \\
(group 2) & Group II & 8 & $33.33 \%$ \\
\hline Embaba & Group I & 4 & $28.57 \%$ \\
(group 3) & Group II & 4 & $16.67 \%$ \\
\hline Bulak & Group I & 4 & $28.57 \%$ \\
(group 4) & Group II & 2 & $8.33 \%$ \\
\hline Misr El Kadima & Group I & 2 & $14.29 \%$ \\
(group 5) & Group II & 2 & $8.33 \%$ \\
\hline Ben El-Sarayat & Group I & 2 & $14.29 \%$ \\
(group 6) & Group II & 0 & $0 \%$ \\
\hline
\end{tabular}


Table-5: Chi-square test according to the lead level concerning the residence $\left(\mathrm{p}<0.003^{*}\right)$.

\begin{tabular}{|c|c|c|c|c|c|c|c|}
\hline $\begin{array}{c}\text { Dependent } \\
\text { Lead }\end{array}$ & & $\begin{array}{c}\text { Group } \\
1\end{array}$ & $\begin{array}{c}\text { Group } \\
2\end{array}$ & $\begin{array}{c}\text { Group } \\
3\end{array}$ & $\begin{array}{c}\text { Group } \\
4\end{array}$ & $\begin{array}{c}\text { Group } \\
5\end{array}$ & total \\
\hline \multirow{3}{*}{$<=$ median } & observed (obs) & 4 & 0 & 4 & 2 & 2 & \\
& expected(exp.) & 4 & 4 & 2 & 1 & 1 & 12 \\
& Obs.-exp. & 0 & -4 & 2 & 1 & 1 & \\
\hline \multirow{3}{*}{$>$ median } & observed (obs) & 4 & 8 & 0 & 0 & 0 & \\
& expected (exp.) & 4 & 4 & 2 & 1 & 1 & 12 \\
& Obs.-exp. & 0 & 4 & -2 & -1 & -1 & \\
\hline Total & observed & 8 & 8 & 4 & 2 & 2 & 24 \\
\hline
\end{tabular}

Table-6: Chi-square test according to the cadmium level concerning the residence ( $\mathrm{p}<$ 0.1992).

\begin{tabular}{|c|c|c|c|c|c|c|c|}
\hline $\begin{array}{c}\text { Dependent } \\
\text { Cadmium }\end{array}$ & & Group & Group & Group & Group & Group & total \\
& & 1 & 2 & 3 & 4 & 5 & \\
\hline \multirow{3}{*}{$<=$ median } & observed (obs) & 2 & 4 & 2 & 2 & 2 & \\
& expected (exp.) & 4 & 4 & 2 & 1 & 1 & 12 \\
& Obs.-exp. & -2 & 0 & 0 & 1 & 1 & \\
\hline \multirow{3}{*}{$>$ median } & observed (obs) & 6 & 4 & 2 & 0 & 0 & \\
& expected (exp.) & 4 & 4 & 2 & 1 & 1 & 12 \\
& Obs.-exp. & 2 & 0 & 0 & -1 & -1 & \\
\hline Total & observed & 8 & 8 & 4 & 2 & 2 & 24 \\
\hline
\end{tabular}




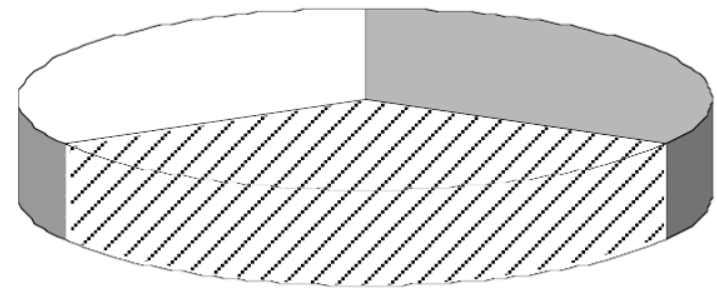

Helwan (33.33)

Shoubra EL_Khema (33.33\%)

\section{Other areas}

$(33.33 \%)$

Figure (1): Distribution of the study population according to residence

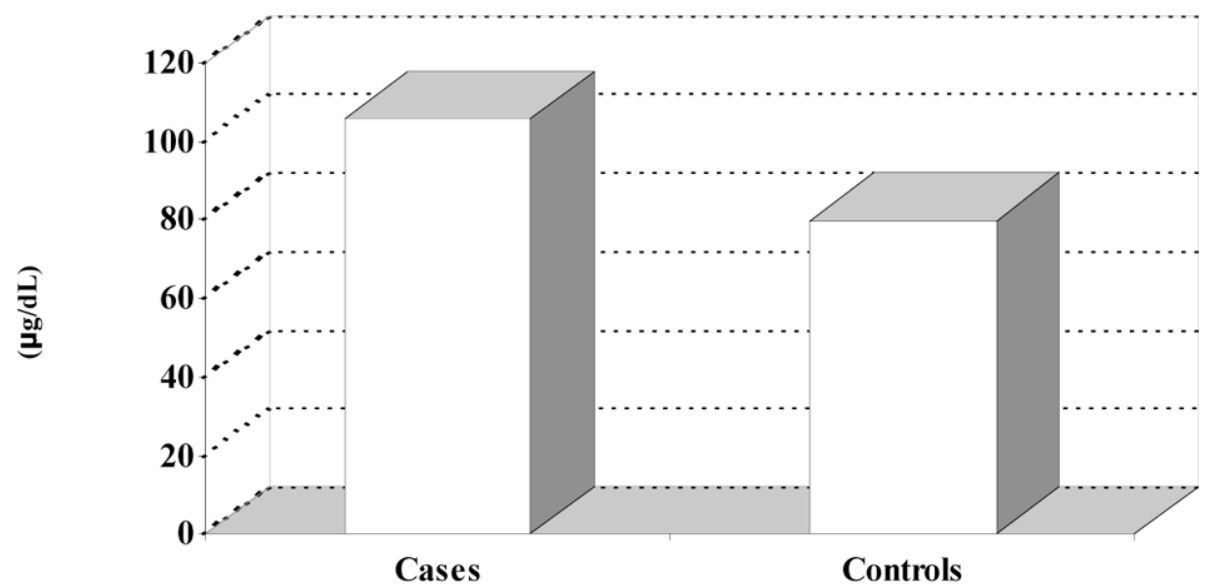

$-(\mu g / d L) * 10$

Figure (2): Mean blood lead level $(\mu \mathrm{g} / \mathrm{dL})$ in cases and controls 


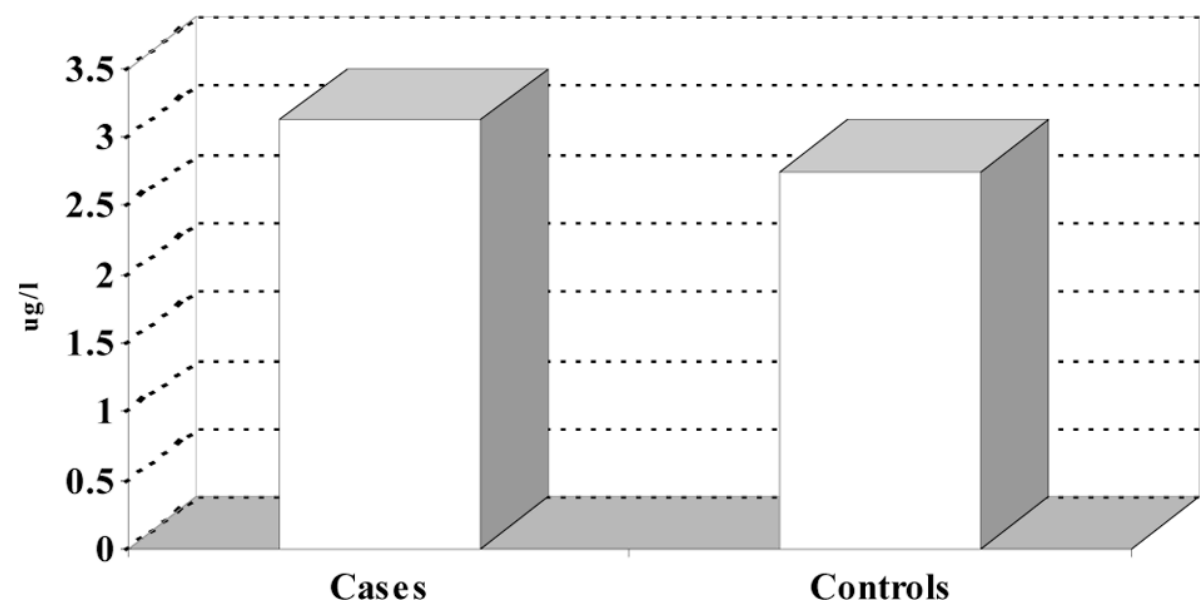

Figure (3): Mean cadmium level $(\mu \mathrm{g} / \mathrm{L})$ in cases and controls

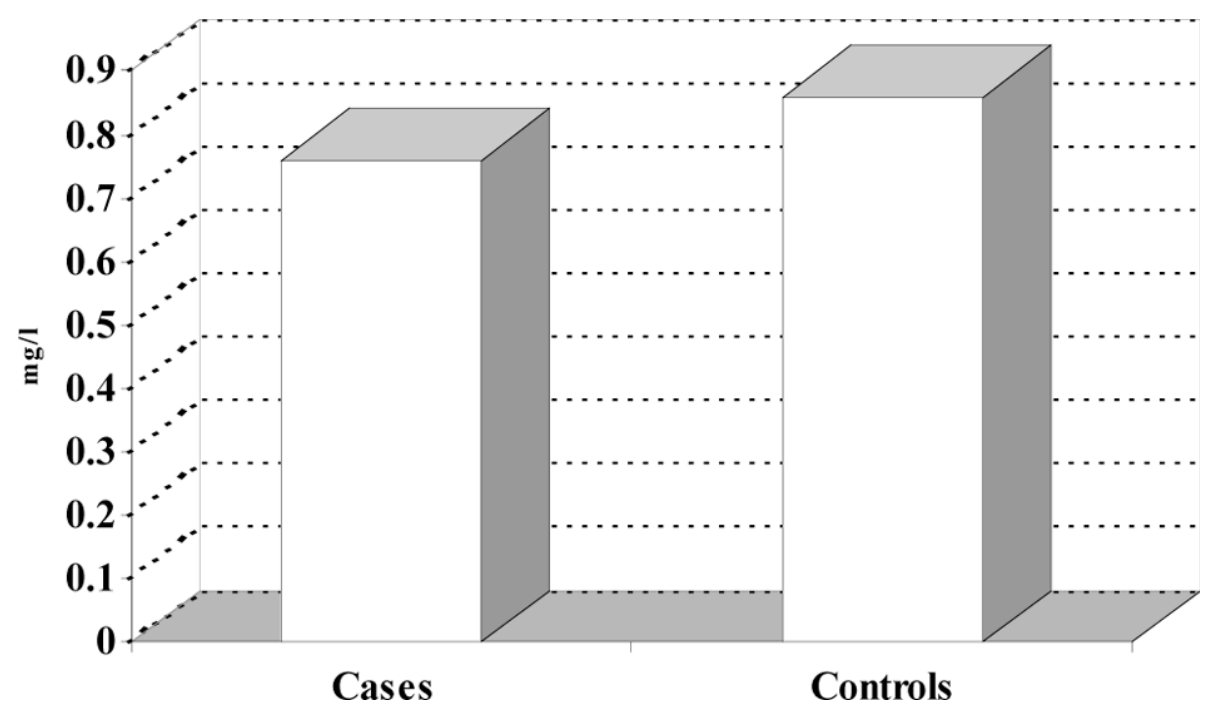

Figure (4): Mean serum zinc (mg/L) in cases and controls 


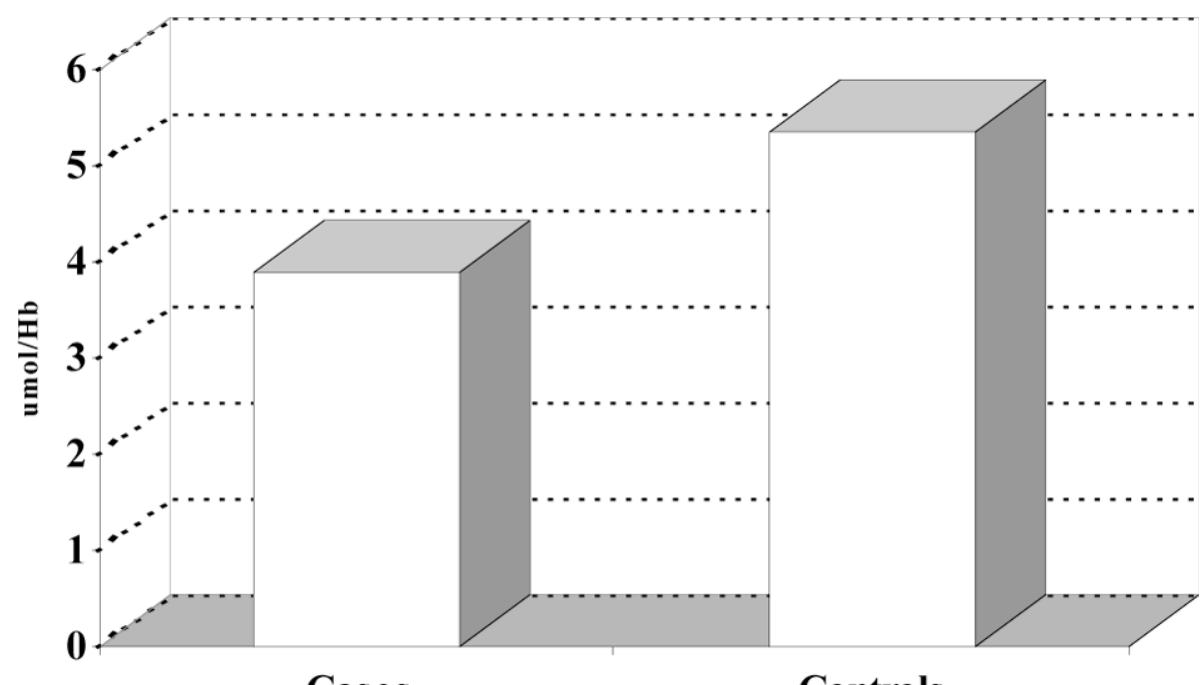

Cases

Controls

Figure (5): Mean serum GSH (mmol/Hb) in cases and controls

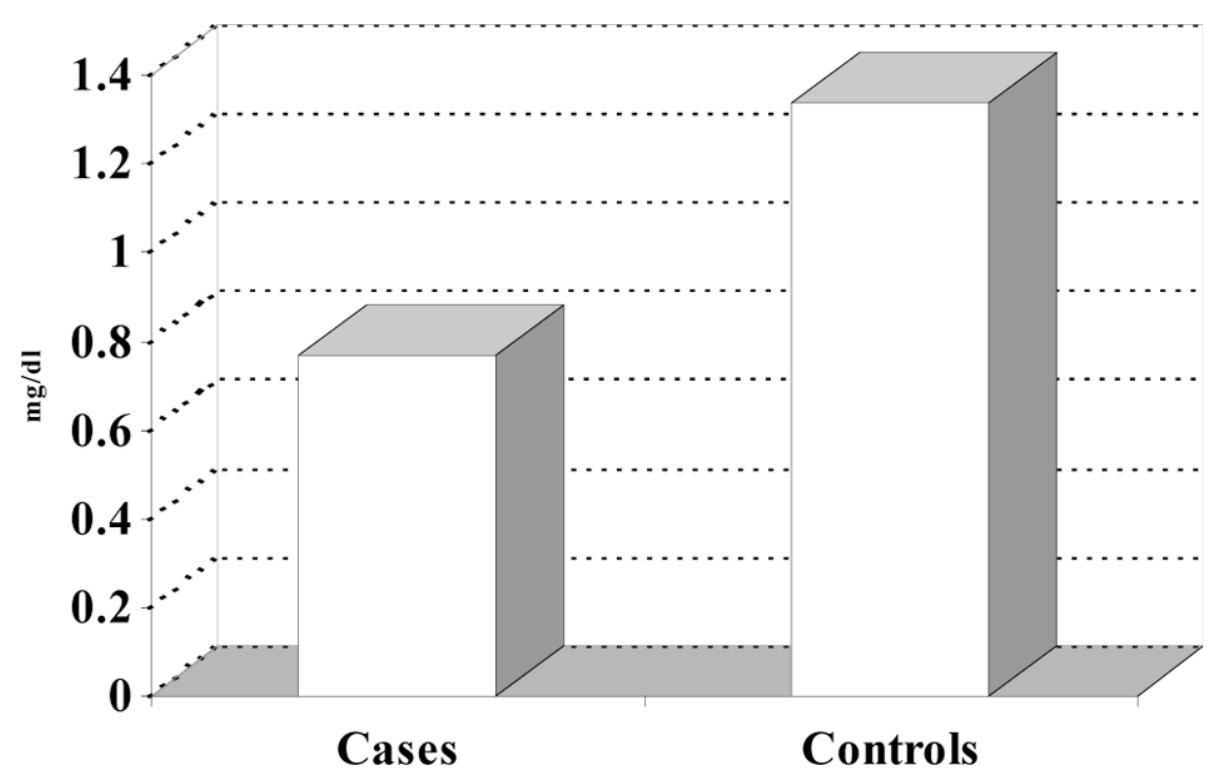

Figure (6): Mean serum Vitamin C (mg/dl) in cases and controls 


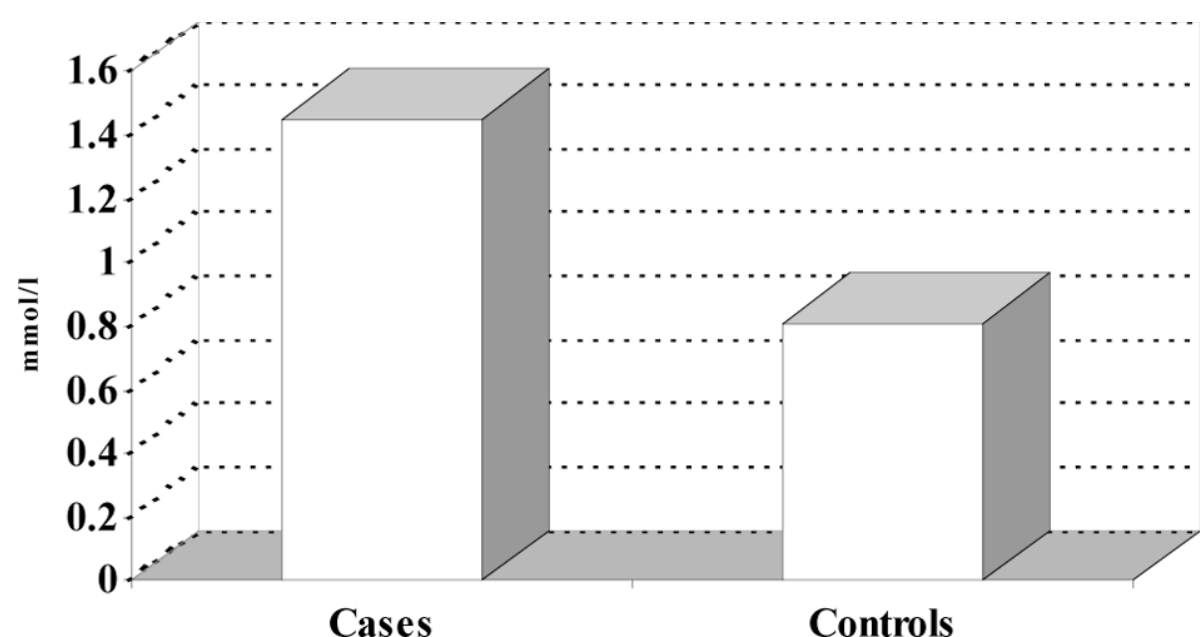

Figure (7): Mean serum MDA (mmol/L) in cases and controls

\section{Discussion}

In humans, lead-induced effects on reproductive functions are well documented in the form of increased number of miscarriages, abortions, and stillbirths. Lead crosses the placental barrier and can easily reach the fetus. Premature membrane rupture and preterm delivery have been associated with high lead content of fetal membranes. There are few data to permit assessment of the extent to which maternal exposure levels in a well-controlled, modern industry are associated with spontaneous abortion. At moderately elevated exposure levels, this risk is likely to be significant (Fischbein, 1998).
In the present study, group II (cases) had statistically significant higher lead and cadmium levels than group I (controls). $66.66 \%$ of cases were living in Helwan and Shoubra El-Khema while the remaining were living in other areas, controls were living in different Cairo areas.

In addition, in the current study, cases had statistically significant lower serum zinc, GSH and serum vitamin $\mathrm{C}$ levels with statistically significant higher serum malondialdehyde levels than controls.

Our findings were in agreement to those previously obtained by Tabacova et al . (1994). They demonstrated that maternal exposure to metals (as indicated by 
blood lead and cadmium) was associated with a decreased antioxidant protection and increased lipid peroxidation evidenced by a decrease in reduced glutathione in blood.

On the same ground, Garza et al. (2006) explained the toxic mechanism of lead as caused by its ability to substitute for other polyvalent cations (particularly divalent cations, such as calcium $[\mathrm{Ca} 2+]$ and zinc $[\mathrm{Zn} 2+]$, decreasing their serum levels, in the molecular machinery of living organisms. These interactions allow lead to affect different biologically significant processes, including metal transport, energy metabolism, apoptosis, ionic conduction, cell adhesion, inter- and intracellular signaling, diverse enzymatic processes, protein maturation, and genetic regulation.

On the same basis, Cekic (1998) found that cadmium is known to compete with copper and zinc in the body and could affect their blood homeostasis, as well as the copper containing proteins. Copper is necessary for the normal physiological activity of numerous enzymes such as cytochrome oxidase, superoxide dismutase and uricase. Superoxide dismutase activity can be affected through competition with zinc.

Many other studies have shown that lead and cadmium impair the renal antioxi- dant defence glutathione and proteinbound $\mathrm{SH}$ groups, resulting in the production of reactive oxygen species. As a consequence enhanced lipid peroxidation, DNA damage and, altered calcium and $\mathrm{SH}$ homeostasis occur (Skoczynska, 1997; Sarkar, et al., 1997; Karmakar, et al., 1999; Patra, et al., 1999 and Shaikh, et al., 1999). These effects have been proved by reduced activities of total superoxide dismutase, manganese-containing superoxide dismutase and selenium dependent glutathione peroxidase enzymes in cadmiumtreated rats (Stajn, et al., 1997).

Moreover, the obtained results of $\mathrm{Vu}-$ ral et al. (2000) and Lagod et al. (2001) indicate that spontaneous abortion is accompanied by a profound disruption of the prooxidant-antioxidant homeostasis towards oxidative stress. Increased free radical activity has been implicated in the pathogenesis of recurrent abortion.

Our results were in agreement to those of Jenkins et al. (2000). They observed that pregnancies that went successfully to term were associated with increased levels of ceruloplasmin and superoxide dismutase (SOD) early in the first trimester. These changes were thought to offer the cell protection from the damage caused by the increased oxidative stress associated with pregnancy. On the contrary, first- 
trimester miscarriage was associated with increased oxidative stress, significantly reduced antioxidant system as manifested by reduced levels of SOD.

Furthermore, Simsek et al. (1998) and Prokopenko et al. (2002) observed that the levels of lipid peroxidation (glutathione) were increased and the plasma levels of vitamin A, E and beta carotene were decreased in women with habitual abortion.

Selenium (one of the antioxidants) is an essential trace mineral required for normal human health and reproduction. In recent years selenium deficiency in humans has been implicated as a risk factor for recurrent pregnancy loss (Rayman, 2000; Rayman \& Rayman, 2002 and Kumar et al., 2002).

A reduction in serum selenium normally occurs in the first trimester of pregnancies that progress to term. However, a further statistically highly significant decrease in serum and hair selenium was observed in those women who miscarried (Barrington et al., 1996 and Al-Kunani et al., 2001).

On the contrary, Nicoll et al. (1999) demonstrated that there is no association between unexplained recurrent miscarriage and reduced selenium status, implying that reduced selenium status is not a factor in the pathogenesis of recurrent miscarriage.

Marinov et al. (1998) found a statistically significant elevation of serum selenium level in cases with missed abortion comparing with those with normal pregnancy.

\section{Conclusion and recommendations}

Although various actions have been taken to decrease the use and distribution of lead in the environment, it remains a significant health hazard. The obtained results indicate that spontaneous abortion is accompanied by a profound disruption of the prooxidant-antioxidant homeostasis towards oxidative stress. Increased free radical activity produced by environmental exposure to lead and cadmium has been implicated in the pathogenesis of spontaneous abortion.

Industrial areas have been accused as environmentally polluted with both lead and cadmium $(66.66 \%$ of cases were living in Shoubra El-Khema and Helwan).

However, long-term studies and epidemiological data are necessary to investigate whether honey consumption can exert overall antioxidant-related health benefits since Gheldof et al. (2003) found that the serum antioxidant capacity increased significantly by $7 \%$ following consumption of buckwheat honey in water. 
Since selenium supplementation resulted in successful pregnancy outcome in veterinary practice, large randomised studies are needed to assess the contribution of selenium in the etiology of spontaneous abortion and the potential benefits of its supplementation during pregnancies.

\section{References}

1. Al-Kunani, A.S.; Knight, R.; Haswell, S.J. et al. (2001): The selenium status of women with a history of recurrent miscarriage. BJOG; 108 (10): 1094-7.

2. Barrington, J.W.; Lindsay, P.; James, D. et al. (1996): Selenium deficiency and miscarriage: a possible link? Br. J. Obstet. Gynaecol.; 103(2): 130-2.

3. Beuther, E. (Ed.): A manual of biochemical method. In red cell metabolism, 3rd. ed., Philadelphia Grune and Straton, pp. 72-136.

4. Cekic, O. (1998): Copper, lead, cadmium and calcium in cataractous lenses. Ophthalmic Res.; 30: 49-53.

5. Elinder, C. and Nordberg, G. (1998): Kidneys. Health effects of cadmium exposure. A review of the literature and a risk estimate. Scand. J. Work Environ. Health; 24: 18-34.

6. Fernandez, F.J. (1975): Micro method for lead detection in whole blood by atomic absorption with use of the graphite furnace. Clin. Chem.; 2: 558-61.

7. Fischbein, A. (1998): Occupational and Environmental Exposure to Lead. In: Environmental and Occupational Medicine. Rom W. N. (Ed.), 3rd ed., Lippincott-Raven Publishrers, Philadelphia, Ch. 68, pp: 973-96.

8. Garza, A.; Vega, R. and Soto, E. (2006): Cellular mechanisms of lead neurotoxicity. Med. Sci. Monit.; 12(3): RA57-65.

9. Hart, B.; Eneman, J.; Gong, Q.; et al. (1995): Increased oxidant resistance of alveolar epithelial type II cells. Isolated from rats following repeated exposure to cadmium aerosols. Toxicol. Lett.; 81: 131-9.

10. Jagota, S.K. and Dany, H.N. (1982): A new colorimetric technique for estimation of vitamin $\mathrm{C}$ using folin phenol reagent. Analyt. Biochem.; 127: 178-82.

11. Jarup, L. (1998): Cardiovascular system. Health effects of cadmium exposure. A review of the literature and a risk estimate. Scand. J. Work Environ. Health; 24: 37.

12. Jenkins, C.; Wilson, R.; Roberts, J. et al. (2000): Antioxidants: their role in pregnancy and miscarriage. Antioxid. Redox. Signal; 2(3): 623-8.

13. Johnson, F.M. (1998): The genetic effects of environmental lead. Mutat. Res.; 410(2): 123-40.

14. Kojima, S.; Sugimura, Y.; Hirukawa, H.; et al. (1992): Effects of dithiocarbamates on testicular toxicity in rats caused by acute exposure to cadmium. Toxicol. Appl. Pharmacol.; 116: 24-9.

15. Karmakar, R.; Roy, S. and Chatterjee, M. (1999): The effects of cadmium on the hepatic and renal levels of reduced glutathione, the activity of glutathione S-transferase and gamma glutamyl transpeptidase. J. Environ. Pathol. Toxicol. Oncol.; 18: 29-35. 
16. Kumar, K.S.; Kumar, A.; Prakash, S. et al. (2002): Role of red cell selenium in recurrent pregnancy loss. J. Obstet. Gynaecol.; 22(2): 181-3.

17. Lagod, L.; Paszkowski, T.; Sikorski, R.et al. (2001): The antioxidant-prooxidant balance in pregnancy complicated by spontaneous abortion. Ginekol. Pol.; 72(12): 1073-8.

18. Marinov, B.; Tsachev, K. and Koleva, V. (1998): The concentration of selenium in the maternal serum in cases of missed abortion. Akush. Ginekol. (Sofiia); 37(1): 15-6.

19. Newman-Taylor, A.J. (1998): Cadmium. In: Environmental and Occupational Medicine. Rom W. N. (Ed.), 3rd ed., Lippincott-Raven Publishers, Philadelphia, Ch. 70, pp: 1005-10.

20. Nicoll, A.E.; Norman, J.; Macpherson, A. et al. (1999): Association of reduced selenium status in the aetiology of recurrent miscarriage. Br. J. Obstet.Gynaecol.; 106(11): 1188-91.

21. Nordberg, G. (1998): Reproductive and developmental effects. Health effects of cadmium exposure. A review of the literature and a risk estimate. Scand. J. Work Environ. Health; 24: 3741.

22. Ohkawo, H.; Ohishi, L.; Nagi, K. et al. (1979): Assay of lipid peroxides in animal tissues by thiobarbituric reaction. Anal. Biochem.; 95: 351-8.

23. Patra, R.; Swarup, D. and Senapati, S. (1999): Effects of cadmium on lipid peroxides and superoxide dismutase in hepatic, renal and testicular tissue of rats. Vet. Hum. Toxicol.; 41: 65-7.

24. Prokopenko, V.M.; Partsalis, G.K.; Pavlova, N.G. et al. (2002): Glutathione-dependent sys- tem of antioxidant defense in the placenta in preterm delivery. Bull. Exp. Biol. Med.; 133(5): $442-3$.

25. Rhainds, M. and Levallois, P. (1997): Effects of maternal cigarette smoking and alcohol consumption on blood lead levels of newborns. Am. J. Epidemiol.; 145(3): 250-7.

26. Rayman, M.P. (2000): The importance of selenium to human health. Lancet; 356(9225): 233-41.

27. Rayman, M.P. and Rayman, M.P. (2002): The argument for increasing selenium intake. Proc. Nutr. Soc.; 61(2): 203-15.

28. Saplakoglu, U. and Iscan, M. (1998): Sister chromatid exchanges in human lymphocytes treated in vitro with cadmium in G0 and S phase of their cell cycles. Mutation Res.; 412: 109-14.

29. Sarkar, S.; Yadav, P. and Bhatnagar, D. (1997): Cadmium-induced lipid peroxidation and the antioxidant system in rat erythrocytes: The role of antioxidants. J. Trace Elem. Med. Biol.; 11: 8-13.

30. Semczuk, M. and Semczuk, S.A. (2001): New data on toxic metal intoxication $(\mathrm{Cd}, \mathrm{Pb}$, and $\mathrm{Hg}$ in particular) and $\mathrm{Mg}$ status during pregnancy. Med. Sci. Monit.; 7(2): 332-340. 31.

Shaikh, Z.; Vu, T. and Zaman, K. (1999): Oxidative stress as a mechanism of chronic cadmiuminduced hepatotoxicity and renal toxicity and protection by antioxidants. Toxicol. Appl. Pharmacol.; 154: 256-63.

32. Simsek, M.; Naziroglu, M.; Simsek, H. et al. (1998): Blood plasma levels of lipoperoxides, glutathione peroxidase, beta carotene, vitamin A and $\mathrm{E}$ in women with habitual abortion. Cell Biochem. Funct.; 16(4): 227-31. 
33. Skoczynska, A. (1997): Lipid peroxidation as a toxic mode of action for lead and cadmium. Med. Pr.; 48: 197-203.

34. Tabacova, S.; Little, R.E.; Balabaeva, L. et al. (1994): Complications of pregnancy in relation to maternal lipid peroxides, glutathione, and exposure to metals. Reprod. Toxicol.; 8(3): 21724.

35. Vural, P.; Akgul, C.; Yildirim, A. et al. (2000): Antioxidant defense in recurrent abortion. Clin. Chim. Acta; 295(1-2): 169-77. 